Г. И. Линег [G. I. Linets]

С. В. Мельников [S. V. Melnikov]

\title{
КРИТЕРИЙ ИДЕНТИФИКАЦИИ ВЕРОЯТНОСТНОЙ МОДЕЛИ СОСТОЯНИЯ СПУТНИКОВЫХ КАНАЛОВ СВЯЗИ
}

\section{CRITERION FOR IDENTIFICATION OF THE PROBABILITY MODEL OF THE STATE OF SATELLITE COMMUNICATION CHANNELS}

ФГАУ ВО Северо-Кавказский Федеральный университет, Институт информационных технологий и телекоммуникаций, г. Ставрополь, Россия, e-mail: territoreer@yandex.ru North Caucasus Federal University, Institute of Information Technologies and Telecommunications, Stavropol, Russia, e-mail: territoreer@yandex.ru

\begin{abstract}
Аннотация. Для идентификации состояния спутниковых каналов связи используются прогнознье методы и модели. Однако, они оченивалот их состояние лииь на качествениом уровне, что не позволяет производить тонкуо настройку характеристик и параметров спутниковых каналов. Подобные модели и методы не могут обеспечивать достоверную идентификацию состояний спутниковых каналов связи и оперативно определять изменение законов распределения случайных величин, связанных с появлением мелкомаситабных неоднородностей в случае динамичного изменения ионосферного слоя, что характерно для быстрьхх замираний сигналов GPS/ГЛОНАСС.

Материаль и методы. На практике, для прогнозирования и исследования распространения радиоволн, наили иирокое применение вероятностные модели, основанные на законах распределения случайных величин Райса, Релея, Накагами и нормального закона распределения. Оперативное улравление и поддержание на требуемом уровне отноиения сигнал иум требует различать состояния спутниковых каналов и идентифицировать их характеристики не только между законами распределения случайньх величин, но и внутри каждого закона. Это позволит обеспечить поддержание количественных и качественных характеристик спутниковых каналов на требуемом уровне. Расстояние между эмпирической и теоретической функииями распределения вероятностей является достаточно эффективной статистикой для проверки гипотез о виде закона распределения вероятностей случайной величинь. К критериям согласия, использующил различные варианты анализа расстояния между теоретической и эмпирической функииями распределения, опносятся: Крамера-фон Мизеса-Смирнова (Омега-квадрат); Колмогорова-Смирнова; Пирсона (Критерий Хи-квадрат); Андерсона-Дарлинга; Купера; Ватсона. В связи с этим, от того, какой критерий будет использован, и насколько адекватно будет проведена оиелжа и идентификачия текуцего состолния спутниковых каналов свлзи, зависит возможность удовлетворения качественных характеристик передаваемьх сигналов GPS/ГЛОНАСС. Для каждого из идентифицируемых законов распределений (ІІакагами, Райса, Релея, норлального закона) были сгенерированы статистические выборки, по 100 выборок с различныи количеством измерений (от 1000 до 1000 000). Таким образом, сумиарное количество выборок различного размера для идентифицируемьх законов распределения составляет 1600. Все исследуемье критерии проверялись на одинаковых выборках. Выборки обрабатьвались с помоџъью библиотеки SсіРу. Разработан алгорити, позволяющий осуществить выбор гипотезы по максииальному значению коэффиииента правдоподобия. Результатом работь алгоритиа является коэффициент правдоподобия, сопоставленньй с каждой из статистических гипотез, при этом предпочтение отдается той гипотезе, которая илеет максимальный коэффициент правдоподобия. С помощью библиотеки Тітеіт проведены измерения времени работы алгоритиов исследуемых критериев в зависимости от разлера выборки для исследуемьлх законов распределений. $B$ статье предложен критерий идентификации состояния спутниковых каналов, обеспечивающий точность не менее $95 \%$. Его адекватность подтверждена даниыми, полученными при мониторинге трансионосферныхх каналов связи $\mathcal{C}$ использованием научного оборудования «Аппаратно-программньй комплекс пассивного монипоринга ионосферы NovAtеl GPStation-6».
\end{abstract}

Данные исследования выполнены при поддержке научного проекта «Разработка роботизированного беспилотного летательного аппарата мультироторного типа с использованием бесплатформенной инерциальной навигационной системы» Федеральной Целевой Программы на 2014-2020 годы (уникальный идентификатор RFMEFI57818X0222) при финансовой поддержке Министерства Науки и Высшего Образования России, на базе ЦКП СКФУ

Ключевые слова: критерий согласия, идентификация закона распределения, трансионосферные каналы связи, GPS, ГЛОНАСС.

Abstracts. Predictive methods and models are used to identify the state of satellite communication channels. However, they evaluate their condition only at a qualitative level, which does not allow fine-tuning the characteristics and parameters of satellite channels. Such models and methods cannot provide reliable identification of the States of satellite communication channels and quickly determine changes in the distribution laws of random variables associated with the appearance of small-scale inhomogeneities in the case of dynamic changes in the ionospheric layer, which is typical for rapid fading of GPS/GLONASS signals. In practice, probabilistic models based on the laws of distribution of random variables of rice, Rayleigh, Nakagami and the normal distribution law are widely used for forecasting and studying the propagation of radio waves. Operational management and maintenance of the signal-to-noise ratio at the required level requires distinguishing the States of satellite channels and identifying their characteristics not only between the laws of distribution of random variables, but also within each law. This will ensure that the quantitative and qualitative characteristics of satellite channels are maintained at the required level. The distance between the empirical and theoretical probability distribution functions is a fairly effective statistic for testing hypotheses about the type of probability distribution law of a random variable. The agreement criteria that use different variants of analyzing the distance between the theoretical and empir- 
ical distribution functions include: Kramer-von Mises-Smirnov (omega-square); Kolmogorov-Smirnov; Pearson (Chi-square Criterion); Anderson-darling; Cooper; Watson's. In this regard, the ability to meet the quality characteristics of transmitted GPS/GLONASS signals depends on which criteria will be used and how well the current state of satellite communication channels will be assessed and identified. For each of the identified distribution laws (Nakagami, rice, Rayleigh, normal law), statistical samples were generated, 100 samples with a different number of dimensions (from 1,000 to 1,000,000). Thus, the total number of samples of various sizes for the identified distribution laws is 1,600. All the studied criteria were tested on identical samples. Selections were processed using the SciPy library. An algorithm has been developed that allows you to select a hypothesis based on the maximum value of the likelihood coefficient. The result of the algorithm is a likelihood coefficient compared with each of the statistical hypotheses, while preference is given to the hypothesis that has the maximum likelihood coefficient. The Timeit library is used to measure the running time of the algorithms of the studied criteria, depending on the sample size for the studied distribution laws. The article offers a criterion for identifying the state of satellite channels, which provides an accuracy of at least $95 \%$. Its adequacy is confirmed by data obtained during monitoring of transionospheric communication channels using scientific equipment "NovAtel GPStation-6 passive ionosphere monitoring Hardware and software complex". These studies were carried out with the support of the scientific project "Development of a multirotor type robotic unmanned aerial vehicle using a strapdown inertial navigation system" of the Federal Target Program for 2014-2020 (unique identifier RFMEFI57818X0222) with the financial support of the Ministry of Science and Higher Education of Russia, based on the NCFU Central research center. GLONASS

Key words: consent criterion, identification of the distribution law, transionospheric communication channels, GPS,

Introduction. One of the important stages in the control and management of transionospheric communication channels is the identification of their states. Based on the results of the analysis of its data, a control action is developed that allows maintaining the signal-to-noise ratio $(\mathrm{S} / \mathrm{N})$ within acceptable limits to ensure the required communication quality. For this purpose, various actions can be taken: increasing the power, changing the frequency of signal transmission, using different coding methods, organizing diversity reception, etc. If the $\mathrm{S} / \mathrm{N}$ ratio is not maintained within acceptable limits, errors in the transmission of GPS / GLONASS signals increase significantly and their quality characteristics do not meet the requirements of practical problems, which is unacceptable.

In practice, for forecasting and studying the propagation of radio waves, probabilistic models based on the distribution laws of Rice, Rayleigh, Nakagami random variables and the normal distribution law have found wide application. These models are basic for the analysis of the qualitative characteristics of satellite channels [1].

The existing practical methods for identifying the state of transionospheric communication channels are based on predictive models $[2,3]$. They use parametric forecasting, which cannot fully meet the requirements of practice due to insufficient forecast accuracy with dynamic changes in the ionosphere, which are characteristic when small-scale irregularities appear in the ionosphere [2]. In addition, they do not explicitly indicate the criterion used and do not develop recommendations for its choice. The difference in states belonging to the same distribution law, characteristic of slow fading, has not been studied sufficiently [2].

Thus, the problem of choosing a criterion for identifying the states of transionospheric communication channels, in the case of dynamically changing ionospheric formations, is relevant and significantly affects the efficiency of processing GPS / GLONASS data and the accuracy of determining the location of objects (for example, unmanned aerial vehicles).

It is necessary that the distribution laws of random variables describing the state of satellite communication channels (Nakagami, Rice, Rayleigh, the normal law) are unambiguously estimated by the used criterion with the required accuracy.

Materials and methods. In works [4-7], criteria are given that are used to compare theoretical and empirical probability distribution functions. The distance between the empirical and theoretical probability distribution functions is a fairly effective statistics for testing hypotheses about the form of the probability distribution law of a random variable. Goodness-of-fit criteria using different versions of the analysis of the distance between the theoretical and empirical distribution functions are presented in [8-12]. These include the following criteria:

- Cramer-von Mises-Smirnov (Omega-square);

- Kolmogorova-Smirnova;

- Pearson (Chi-square test);

- Anderson-Darling;

- Cooper;

- Watson.

The Cramer-von Mises-Smirnov criterion is designed to test simple hypotheses about the belonging of the analyzed sample to a fully known law.

When testing simple hypotheses, the criterion is free of distribution, that is, it does not depend on the type of law with which agreement is checked [11]. The hypothesis being tested is rejected when the statistics are large. In $[11,13]$, it was established that when testing complex hypotheses, where the estimate of a scalar or vector distribution parameter is calculated from the same sample, nonparametric goodness-of-fit tests lose the property of freedom from distribution. In this case, the distributions of statistics of nonparametric goodness-of-fit tests depend on a number of factors: the type of the observed law corresponding to a fair testable hypothesis; the type of parameter being evaluated; 
the number of estimated parameters. The differences in the limiting distributions of the same statistics when testing simple and complex hypotheses are so significant that it is impossible to neglect it $[11,13]$.

In the Kolmogorov-Smirnov goodness-of-fit test, it is advisable to use statistics with the Bolshev's correction [14]. The distribution of this statistic, given the validity of the hypothesis being tested, quickly converges to the Kolmogorov distribution, and for $\mathrm{n}>25$ the dependence on the sample size can be neglected [14]. Statistics like $D_{n}=\sup \left|F_{n}(x)-F(x)\right|$.

The Anderson-Darling test is acceptable for a sample size $n \geq 25$ [15]. The check can be carried out for any type of distribution, if the distribution parameters are assumed to be known. If the statistics are large, the hypothesis being tested is rejected. Statistics of the form [15]

$$
S_{\Omega}=-n-2 \sum_{i=1}^{n}\left(\frac{2 i-1}{2 n} \ln \left(F\left(x_{i}, \theta\right)\right)+\left(1-\frac{2 i-1}{2 n} \ln \left(1-F\left(x_{i}, \theta\right)\right)\right) .\right.
$$

Cooper's goodness test is a development of the Kolmogorov goodness-of-fit test and was proposed to test simple hypotheses about the fact that the analyzed sample belongs to a fully known law [16]. If the statistics are large, the hypothesis being tested is rejected. Statistics like $D_{n}^{+}=\max \left(\frac{i}{n}-F\left(x_{i}, \theta\right)-\frac{i-1}{n}\right), D_{n}^{-}=\max \left(F\left(x_{i}, 0\right)-\frac{i-1}{n}\right)$.

The Watson goodness test is a development of the Cramer - Mises - Smirnov goodness test [16]. If the statistics are large, the hypothesis being tested is rejected. Statistics like

$$
U_{n}^{2}=\sum_{i=1}^{n}\left(F\left(x_{i}, \theta\right)-\frac{i-0.5}{n}\right)^{2}-n\left(\frac{1}{n} \sum_{i=1}^{n} F\left(x_{i}, \theta\right)-0.5\right)^{2}+\frac{1}{12 n} .
$$

Required:

1. Investigate the above criteria for the corresponding statistics on previously known test samples of the laws of distribution of random variables and determine a criterion with an identification accuracy of no worse than $95 \%$.

2. Check the adequacy of the selected criterion on statistical samples obtained using the hardware and software complex for passive monitoring of the ionosphere NovAtel GPStation-6.

Results and discussion. Statistical samples were generated for each of the identified distribution laws (Nakagami, Rice, Rayleigh, normal law). The samples were processed using the SciPy library.

For each of the distribution laws defined above, 100 samples were obtained with a different number of measurements (from 1,000 to 1,000,000). Thus, the total number of samples of different sizes for the identified distribution laws is 1600 . All the studied criteria were tested on the same samples.

To solve the identification problem, an algorithm has been developed that provides:

1. Collection of experimental statistics of empirical distribution.

2. Calculation of the mathematical expectation and variance of the sample of the empirical distribution.

3. Construction of the differential function of the empirical distribution.

4. Calculation of the mathematical expectation and variance of the empirical distribution.

5. Construction of differential distribution functions for each of the reference distributions with mathematical expectation and variance of the empirical distribution.

6. Determination of the coefficient of likelihood of the sample under study for each criterion for the assumed distributions.

7. Ranking the results of testing hypotheses according to the maximum likelihood ratio.

8. Selection of a hypothesis based on the maximum value of the likelihood coefficient.

Table 1

Sample sizes for testing identification criteria

\begin{tabular}{|c|c|c|c|c|}
\hline \multirow{2}{*}{$\begin{array}{c}\text { Number of measure- } \\
\text { ments in the sample }\end{array}$} & Normal & Rayleigh & Ristribution law & Nakagami \\
\cline { 2 - 5 } & 100 & 100 & 100 & 100 \\
\hline 1000 & 100 & 100 & 100 & 100 \\
\hline 10000 & 100 & 100 & 100 & 100 \\
\hline 100000 & 100 & 100 & 100 & 100 \\
\hline 1000000 & & & & \\
\hline
\end{tabular}

The result of the algorithm is the likelihood coefficient compared with each of the statistical hypotheses, with preference given to the hypothesis with the maximum likelihood coefficient. An example of the algorithm for the Anderson-Darling test of the studied sample of 1000 measurements is presented in Table 2. For this test, the maximum likelihood coefficient is 6.485299 , which corresponds to the identification of Nakagami's law.

Table 2

An example of the algorithm for the Anderson-Darling test

\begin{tabular}{|c|c|c|c|}
\hline Criterion & Initial distribution & Estimated distribution & Coefficient of probability \\
\hline \multirow{2}{*}{ Anderson-Darling } & \multirow{2}{*}{ Nakagami } & Rice & 4,37399 \\
\cline { 3 - 4 } & & Nakagami & 6,485299 \\
\cline { 3 - 4 } & & Normal & 4,1812 \\
\hline
\end{tabular}




\begin{tabular}{|c|c|c|c|}
\hline & & Rayleigh & 4,2382 \\
\hline Total time & & & $0,653 \mathrm{c}$. \\
\hline
\end{tabular}

The greatest interest is the comparison of accuracy criteria and distribution laws of random variables, since It is investigated that the distribution for some values of their arguments has a sufficient form.

Using the algorithm presented above, a study was carried out to select a criterion. Determined on a given plural. The test results are summarized in Table 3.

Obviously, the Omega-square test has the worst result. The standard implementation of the criterion, taken as a basis, is capable of qualitatively determining only the normal distribution. At the same time, the Kolmogorov-Smirnov, Cooper and Watson criteria show a fairly good result. Acceptable for them is the choice of 1000 elements, which allows using the data for the requirements for the laws of distributed random variables in practical application.

Figure 2 shows probability graphs. Similar graphs were obtained for the laws of Rayleigh, Rice, Nakagami.

Using the time library, which measures the running time of the algorithms, the criteria are investigated depending on the size. The results of measuring the average running time of algorithms and empirical selection criteria in accordance with Rice's law are presented in Table 4 and Figure 3.

The analysis showed that the Chi-square test has the longest average running time of the algorithm. The rest of the algorithms have comparable average running time of the algorithms. Taken together, the studied characteristics determine the laws, the best indicators in terms of probability and average time have the Kolmogorov-Smirnov test.

Values of probabilities of the correct base of empirical distributions

Table 3

\begin{tabular}{|c|c|c|c|c|}
\hline \multicolumn{5}{|c|}{ Normal law } \\
\hline \multirow{2}{*}{ Criterion } & \multicolumn{4}{|c|}{ Sample size } \\
\hline & 1000 & 10000 & 100000 & 1000000 \\
\hline Kolmogorov-Smirnov & $96 \%$ & $97 \%$ & $98 \%$ & $98 \%$ \\
\hline Cooper's & $95 \%$ & $96 \%$ & $96 \%$ & $96 \%$ \\
\hline Chi-square & $75 \%$ & $75 \%$ & $78 \%$ & $79 \%$ \\
\hline Omega square & $86 \%$ & $88 \%$ & $90 \%$ & $90 \%$ \\
\hline Anderson-Darling & $80 \%$ & $85 \%$ & $87 \%$ & $88 \%$ \\
\hline Watson & $94 \%$ & $95 \%$ & $95 \%$ & $95 \%$ \\
\hline \multicolumn{5}{|c|}{ Nakagami's law } \\
\hline Kolmogorov-Smirnov & $97 \%$ & $97 \%$ & $97 \%$ & $97 \%$ \\
\hline Cooper's & $95 \%$ & $95 \%$ & $95 \%$ & $96 \%$ \\
\hline Chi-square & $70 \%$ & $72 \%$ & $74 \%$ & $75 \%$ \\
\hline Omega square & $0 \%$ & $0 \%$ & $0 \%$ & $0 \%$ \\
\hline Anderson-Darling & $80 \%$ & $81 \%$ & $82 \%$ & $84 \%$ \\
\hline Watson & $95 \%$ & $95 \%$ & $95 \%$ & $95 \%$ \\
\hline \multicolumn{5}{|c|}{ Rice's law } \\
\hline Kolmogorov-Smirnov & $95 \%$ & $95 \%$ & $95 \%$ & $95 \%$ \\
\hline Cooper's & $94 \%$ & $95 \%$ & $95 \%$ & $95 \%$ \\
\hline Chi-square & $75 \%$ & $75 \%$ & $78 \%$ & $79 \%$ \\
\hline Omega square & $0 \%$ & $0 \%$ & $0 \%$ & $0 \%$ \\
\hline Anderson-Darling & $80 \%$ & $85 \%$ & $87 \%$ & $88 \%$ \\
\hline Watson & $95 \%$ & $95 \%$ & $95 \%$ & $95 \%$ \\
\hline \multicolumn{5}{|c|}{ Rayleigh's law } \\
\hline Kolmogorov-Smirnov & $97 \%$ & $97 \%$ & $98 \%$ & $98 \%$ \\
\hline Cooper's & $95 \%$ & $95 \%$ & $96 \%$ & $96 \%$ \\
\hline Chi-square & $72 \%$ & $74 \%$ & $74 \%$ & $75 \%$ \\
\hline Omega square & $0 \%$ & $0 \%$ & $0 \%$ & $0 \%$ \\
\hline Anderson-Darling & $65 \%$ & $71 \%$ & $72 \%$ & $72 \%$ \\
\hline Watson & $95 \%$ & $95 \%$ & $95 \%$ & $95 \%$ \\
\hline
\end{tabular}

Table 4

Average running time of criteria identification algorithms for distribution of empirical samples according to Rice's law

\begin{tabular}{|c|c|c|c|c|}
\hline \multirow{2}{*}{ Criterion } & \multicolumn{4}{|c|}{ Размер выборки } \\
\hline & 1000 & 10000 & 100000 & 1000000 \\
\hline Kolmogorov-Smirnov & $0,2688 \mathrm{c}$. & $0,688 \mathrm{c}$. & $1,596 \mathrm{c}$. & $1,76 \mathrm{c}$ \\
\hline Cooper's & $0,328 \mathrm{c}$ & $0,67 \mathrm{c}$ & $1,75 \mathrm{c}$ & $1,83 \mathrm{c}$. \\
\hline Chi-square & $0,479 \mathrm{c}$. & $0,848 \mathrm{c}$. & $2,72 \mathrm{c}$ & $5,09 \mathrm{c}$ \\
\hline Anderson-Darling & $0,578 \mathrm{c}$ & $0,823 \mathrm{c}$. & $1,654 \mathrm{c}$. & $1,896 \mathrm{c}$. \\
\hline Watson & $0,487 \mathrm{c}$. & $0,563 \mathrm{c}$. & $1,647 \mathrm{c}$. & $1,913 \mathrm{c}$ \\
\hline
\end{tabular}

In order to check the adequacy of the research results, the empirical distributions obtained with the use of the NovAtel GPStation-6 hardware-software complex for passive ionosphere monitoring were tested. For testing, the criteria of Kolmogorov-Smirnov, Cooper and Watson were used. The data received from the GPStation-6 receiver were pro- 
cessed manually. We studied 100 samples with a predetermined distribution of 10,000 elements. The analysis showed the closeness of the results of the studies. The best criterion was the Kolmogorov-Smirnov test, which has an identification accuracy of more than $95 \%$. Cooper and Watson's tests respectively identified the empirical distribution with 90 and 93 percent accuracy.
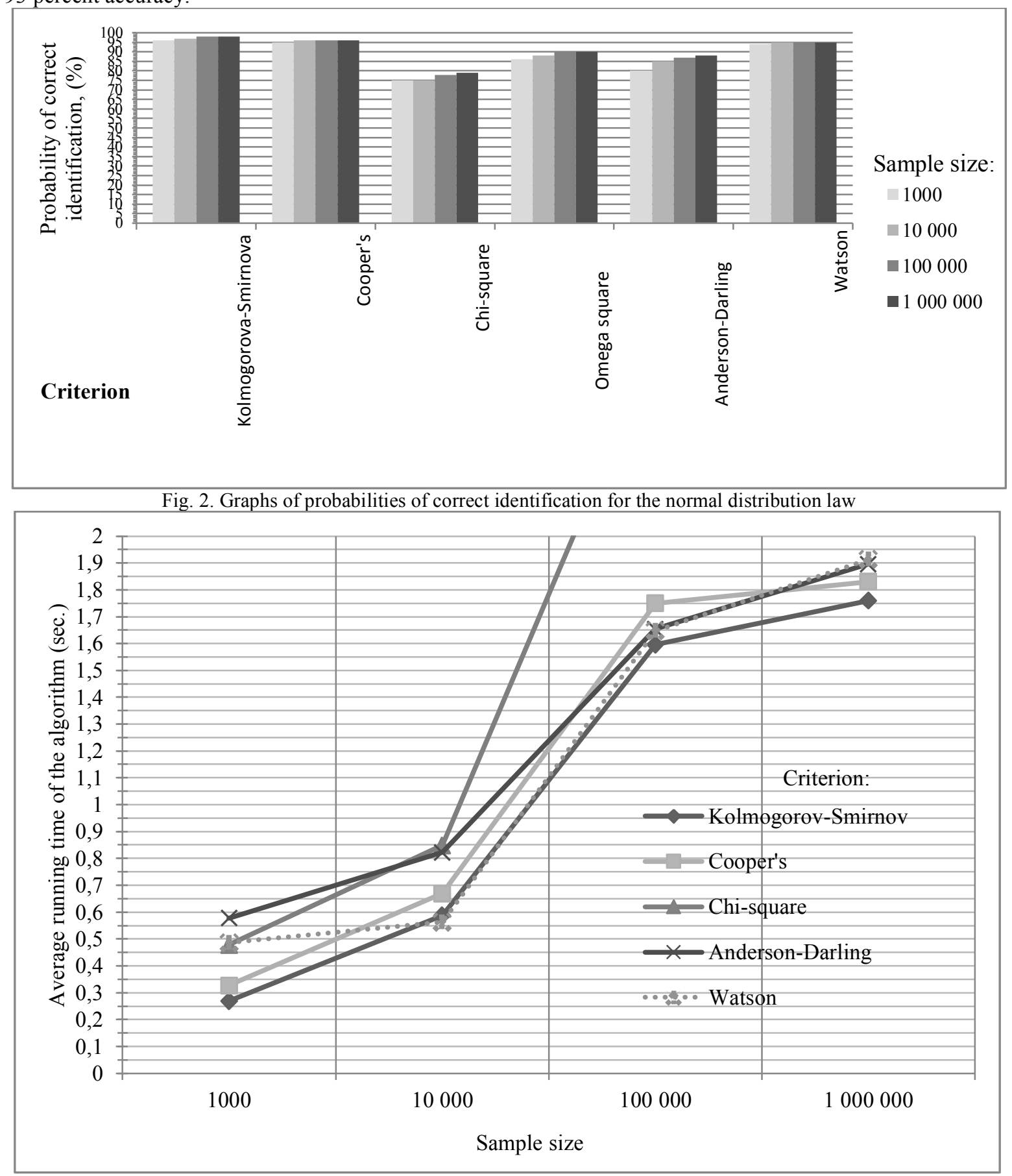

Fig. 3. Graph of the dependence of the average identification time of empirical samples distributed according to Rice's law

Conclusions / Conclusion. In this work, a criterion is chosen for identifying the distribution law describing the disturbances of the ionosphere in transionospheric communication channels. The best criterion is the KolmogorovSmirnov criterion, since with relatively close mean values of the identification time of the distribution laws with the Cooper and Watson criteria, it has the best accuracy. The use of this criterion will make it possible to reasonably optimize the classification thresholds for the states of transionospheric communication channels of the laws of distribution of random variables. In the future, it is advisable to conduct additional research using it to identify the following empirical distributions: Beckman, Hoyt, truncated normal law. 


\section{ЛИТЕРАТУРА}

1. Рек. MCЭ-R P.1057-5 (12/2017). Распределения вероятностей, касаюпихся моделирования распространения радиоволн. Серия р. Распространение радиоволн [Электронный ресурс] // Международный союз электросвязи. URL: https://www.itu.int/dms_pubrec/itu-r/rec/p/R-REC-P.1057-5-201712-I!!PDF-R.pdf (дата обрапения: 05.05.2020).

2. Методы диагностики характеристик ионосферы для заданного региона и коррекция моделей ионосферы в интересах повышения точности прогнозирования распространения радиоволн декаметрового диапазона / В. И. Арефьев, М. К. Кочерова, А. Б. Талалаев, В. В. Тихонов // Вестник тверского государственного университета. Серия: прикладная математика. 2016. № 1. С. 33-51.

3. Беккер С. 3. Вероятностно-статистические модели нижней невозмушенной среднеширотной ионосферы, верифицированные по данным наземных радиофизических измерений: дис. ... канд. физ.-мат. наук. Москва, 2018.129 с.

4. Лемешко Б. Ю., Горбунова А. А. О применении и мощности непараметрических критериев согласия Купера, Ватсона и Жанга // Измерительная техника. 2013. № 5. С. 3-9.

5. Кобзарь А. И. Прикладная математическая статистика. М.: Физматлит, $2006.816 \mathrm{c}$.

6. Компьютерное моделирование и исследование вероятностных закономерностей / Б. ІО. Лемешко, А. А. Горбунова, С. Б. Лемешко, С. ІІ. Постовалов, А. П. Рогожников, Е. В. Чимитова // Вестник Томского государственного университета. Управление, вычислительная техника и информатика. 2013. № 1 (22). С. 74-85

7. Лагутин М. Б. Наглядная математическая статистика: учебное пособие, 3-е изд., испр. М.: Бином. Лаборатория знаний, 2013. $472 \mathrm{c}$

8. Вожов С. С., Чимитова Е. В. Проверка гипотезы о виде распределения по интервальным данным // Вестник Томского государственного университета. Управление, вычислительная техника и информатика. 2016. № 1 (34). С. 35-42

9. On some goodness-of-fit tests and their connection to graphical methods with uncensored and censored data / C. CastroKuriss, M. Huerta, V. Leiva, A. Tapia // Advances in Intelligent Systems and Computing. 2020. № 1001. P. 157-183.

10. Р 50.1.037-2002. Рекомендации по стандартизации. Прикладная статистика. Правила проверки согласия опытного распределения с теоретическим. Часть II. Непараметрические критерии. - М.: Изд-во стандартов. 2002. -64 с

11. Kac M., Kiefer J., Wolfowitz J. On Tests of Normality and Other Tests of Goodness of Fit Based on Distance Methods // The Annals of Mathematical Statistics. 1955. № 26. P. 189-211.

12. Filion, G. J. The signed Kolmogorov-Smirnov test: Why it should not be used // GigaScience. 2015. № 4 (1). Art. 9.

13. Мартынов Г. В. Критерии омега-квадрат. М.: Наука, 1978. 80 c.

14. Большев Л. Н. Асимптотические пирсоновские преобразования // Теория вероятностей и ее применения. 1963. T. 8. № 2. C. 129-155

15. Большев Л. Н., Смирнов Н. В. Таблицы математической статистики. М.: Наука, 1983. 416 с.

16. Лемешко Б. ІО., Горбунова А. А. Применение непараметрических критериев согласия Купера и Ватсона при проверке сложных гипотез // Измерительная техника. 2013. № 9. С. 14-21.

\section{REFERENCES}

1. Rek. MSEh-R P.1057-5 (12/2017). Raspredeleniya veroyatnostei, kasayushchikhsya modelirovaniya rasprostraneniya radiovoln. Seriya r. Rasprostranenie radiovoln [Ehlektronnyi resurs] // Mezhdunarodnyi soyuz ehlektrosvyazi. URL: https://www.itu.int/dms pubrec/itu-r/rec/p/R-REC-P.1057-5-201712-I!!PDF-R.pdf (data obrashcheniya: 05.05.2020).

2. Metody diagnostiki kharakteristik ionosfery dlya zadannogo regiona i korrektsiya modelei ionosfery $\mathrm{v}$ interesakh povysheniya tochnosti prognozirovaniya rasprostraneniya radiovoln dekametrovogo diapazona / V. I. Aref'ev, M. K. Kocherova, A. B. Talalaev, V. V. Tikhonov // Vestnik tverskogo gosudarstvennogo universiteta. Seriya: prikladnaya matematika. 2016. № 1. S. 33-51.

3. Bekker S. Z. Veroyatnostno-statisticheskie modeli nizhnei nevozmushchennoi sredneshirotnoi ionosfery, verifitsirovannye po dannym nazemnykh radiofizicheskikh izmerenii : dis. ... kand. fiz.-mat. nauk. Moskva, 2018. $129 \mathrm{~s}$.

4. Lemeshko B. Yu., Gorbunova A. A. O primenenii i moshchnosti neparametricheskikh kriteriev soglasiya Kupera, Vatsona i Zhanga // Izmeritel'naya tekhnika. 2013. № 5. S. 3-9.

5. Kobzar' A. I. Prikladnaya matematicheskaya statistika. M.: Fizmatlit, 2006. $816 \mathrm{~s}$.

6. Komp'yuternoe modelirovanie i issledovanie veroyatnostnykh zakonomernostei / B. Yu. Lemeshko, A. A. Gorbunova, S. B. Lemeshko, S. N. Postovalov, A. P. Rogozhnikov, E. V. Chimitova // Vestnik Tomskogo gosudarstvennogo universiteta. Upravlenie, vychislitel'naya tekhnika i informatika. 2013. № 1 (22). S. 74-85

7. Lagutin M. B. Naglyadnaya matematicheskaya statistika : uchebnoe posobie, 3-e izd., ispr. M.: Binom. Laboratoriya znanii, 2013. $472 \mathrm{~s}$

8. Vozhov S. S., Chimitova E. V. Proverka gipotezy o vide raspredeleniya po interval'nym dannym // Vestnik Tomskogo gosudarstvennogo universiteta. Upravlenie, vychislitel'naya tekhnika i informatika. 2016. № 1 (34). S. 35-42

9. On some goodness-of-fit tests and their connection to graphical methods with uncensored and censored data / C. CastroKuriss, M. Huerta, V. Leiva, A. Tapia // Advances in Intelligent Systems and Computing. 2020. № 1001. R. 157-183.

10. R 50.1.037-2002. Rekomendatsii po standartizatsii. Prikladnaya statistika. Pravila proverki soglasiya opytnogo raspredeleniya s teoreticheskim. Chast' II. Neparametricheskie kriterii. - M.: Izd-vo standartov. 2002. - 64 s.

11. Kac M., Kiefer J., Wolfowitz J. On Tests of Normality and Other Tests of Goodness of Fit Based on Distance Methods // The Annals of Mathematical Statistics. 1955. № 26. P. 189-211.

12. Filion, G. J. The signed Kolmogorov-Smirnov test: Why it should not be used // GigaScience. 2015. № 4 (1). Art. 9.

13. Martynov G. V. Kriterii omegA-kvadrat. M.: Nauka, 1978. $80 \mathrm{~s}$.

14. Bol'shev L. N. Asimptoticheskie pirsonovskie preobrazovaniya// Teoriya veroyatnostei i ee primeneniya. 1963. T. 8.

№ 2. S. 129-155

15. Bol'shev L. N., Smirnov N. V. Tablitsy matematicheskoi statistiki. M.: Nauka, 1983. 416 s.

16. Lemeshko B. Yu., Gorbunova A. A. Primenenie neparametricheskikh kriteriev soglasiya Kupera i Vatsona pri proverke slozhnykh gipotez // Izmeritel'naya tekhnika. 2013. № 9. S. 14-21. 
These studies were carried out with the support of the scientific project "Development of a robotic unmanned aerial vehicle of a multi-rotor type using a strapdown inertial navigation system" of the federal target program for 2014-2020 (unique identifier rfmefi57818x0222) with the financial support of the Ministry of Science and Higher Education of Russia, based on the central administrative center of the skfu s the use of scientific equipment "Hardware and software complex for passive monitoring of the ionosphere NovAtel GPStation-6".

Conflict of Interest Information: The authors declare no conflict of interest.

Shares of participation in writing an article:

Linets Gennady Ivanovich - 50\% (problem statement, leadership, analysis of results).

Melnikov Sergey Vladimirovich - 50\% (conducting experiments, data processing, article writing and presentation).

\section{OБ ABTOPAX | ABOUT AUTHORS}

Линец Геннадий Иванович, доктор технических наук, профессор, Институт информационных технологий и телекоммуникаций, СКФУ, e-mail: territoreer@yandex.ru

Linets Gennady Ivanovich, Doctor of Technical Sciences, Professor, Institute of Information Technologies and Telecommunications, NCFU

Мельников Сергей Владимирович, аспирант, Институт информационных технологий и телекоммуникаций, СКФУ

Melnikov Sergey Vladimirovich, post-graduate student, Institute of Information Technologies and Telecommunications, NCFU

Дата поступления в редакцию: 12.03.2020

После рецензирования: 23.04.2020

Дата принятия к публикации: 23.05.2020 